\title{
The 1991 Sierra Madre Earthquake Sequence in Southern California: Seismological and Tectonic Analysis
}

\author{
by Egill Hauksson
}

\begin{abstract}
The $\left(M_{L} 5.8\right)$ Sierra Madre earthquake of 28 June 1991 occurred at a depth of $12 \mathrm{~km}$ under the San Gabriel Mountains of the central Transverse Ranges. Since at least 1932 this region had been quiescent for $M \geqq 3$. The mainshock focal mechanism derived from first-motion polarities exhibited almost pure thrust faulting, with a rake of $82^{\circ}$ on a plane striking $N 62^{\circ} \mathrm{E}$ and dipping $50^{\circ}$ to the north. The event appears to have occurred on the Clamshell-Sawpit fault, a splay of the Sierra Madre fault zone. The aftershock sequence following the mainshock occurred at a depth of 9 to $14 \mathrm{~km}$ and was deficient in small earthquakes, having a $b$ value of 0.6 . Twenty nine single-event focal mechanisms were determined for aftershocks of $M>1.5$. The 4-km-long segment of the Clamshell-Sawpit fault that may have ruptured in the mainshock is outlined by several thrust focal mechanisms with an east-northeast-striking fault plane dipping to the north. To the west, several thrust aftershocks with east-striking nodal planes suggest some complexity in the aftershock faulting, such as a curved rupture surface. In addition, several strike-slip and normal faulting events occurred along the edges of the mainshock fault plane, indicating secondary tear faulting. The tectonic stress field driving the coexisting left-lateral strike-slip and thrust faults in the northern Los Angeles basin is north-south horizontal compression with vertical intermediate or minimum principal stress axis.
\end{abstract}

\section{Introduction}

The $1991\left(M_{L}\right.$ 5.8) Sierra Madre sequence occurred north of the Los Angeles basin, beneath the San Gabriel Mountains in southern California at 14:43 (UTC) on 28 June 1991 (Fig. 1). The San Gabriel Mountains are a part of the central Transverse Ranges, a broad region of east-trending mountain blocks that have been thrust upward and southward along north-dipping thrust faults. The Transverse Ranges have a profound effect on the tectonics of southern California because all of the northwest-trending faults of the San Andreas system, except the San Andreas fault itself, terminate as they approach the Transverse Ranges (Morton and Yerkes, 1987). The north-south compressive deformation of the Transverse Ranges can be attributed to convergence across the "big bend" of the San Andreas fault between Gorman and Desert Hot Springs (Morton and Yerkes, 1987).

The 1991 Sierra Madre earthquake sequence occurred within a seismically quiescent part of the Sierra Madre fault zone (Fig. 2). The CIT/USGS earthquake catalog for southern California since 1932 shows that the background seismicity is almost absent north of the central section of the frontal fault system, compared to near the eastern and western ends of the range. Pechmann (1987), who studied the seismicity near the eastern and western ends of the fault zone, determined focal mechanisms for 22 small earthquakes that occurred during 1974 to 1977 . He found mostly diffuse seismicity unrelated to major Quaternary faults and focal mechanisms showing reverse faulting and some strike-slip faulting on eaststriking planes. Because the Sierra Madre earthquake occurred in a region that had been seismically quiescent, it provided new information about the configuration of the Sierra Madre fault zone at depth.

The Sierra Madre earthquake caused substantial damage in communities in northern San Gabriel Valley. The Modified Mercalli Intensity (MMI) for the earthquake is shown here as it was mapped by Stover and Reagor (1991) (Fig. 3). The two pockets of MMI of VII are centered on the cities of Pasadena and Sierra Madre. The 1991 remotely located Sierra Madre earthquake caused damage of approximately $\$ 40$ million, which is significantly smaller than the damage of $\$ 360$ million caused by the $1987\left(M_{L} 5.9\right)$ Whittier Narrows earthquake located under the heavily urbanized San Gabriel Valley (Hauksson et al., 1988). 
The Sierra Madre earthquake was a part of a recent flurry of moderate-sized earthquakes in the Los Angeles basin. From 1930 to $1986, M \geqq 5$ earthquakes occurred every 5 to $7 \mathrm{yr}$ in the greater Los Angeles basin area (Hauksson, 1990). From 1987 to 1991, the following four significant earthquakes occurred: the $1987\left(M_{L} 5.9\right)$ Whittier Narrows (Hauksson et al., 1988; Hauksson and Jones, 1989), 1988 ( $M_{L} 5$ ) Pasadena (Jones et al., 1990), $1989\left(M_{L} 5\right)$ Malibu, $1990\left(M_{L} 5.2\right)$ Upland (Hauksson and Jones, 1991), and $1991\left(M_{L} 5.8\right)$ Sierra Madre earthquake. In addition, several smaller clusters of seismicity with mainshock magnitude in the range of 4 to 4.8 also occurred.

\section{Sierra Madre Fault Zone}

The 1991 Sierra Madre earthquake is the second damaging historic event to occur within the Sierra Madre fault zone, the first being the $1971\left(M_{W} 6.6\right)$ San Fernando earthquake. The Sierra Madre fault zone follows the base of the mountains from Cajon Pass to San Fernando in a series of arcuate 15 to $25-\mathrm{km}$-long fault segments (Fig. 4a). (Proctor et al., 1972; Crook et al., 1987). The surficial fault-zone geology of the Sierra Madre fault is well understood from the work of Crook et al. (1987). They provided evidence on the location of fault strands and the style and timing of fault movements during the Quaternary from San Gabriel Canyon to San Fernando Valley (Fig. 4). Only the Sierra Madre B segment, adjacent to the faults that broke during the 1971 San Fernando earthquake, also showed evidence of Holocene movement (Fig. 4a). Because they found no evidence for Holocene fault movement along Sierra Madre C and D segments through La Canada, Altadena, Sierra Madre, and Azusa, they concluded that the recurrence interval between such major earthquakes through the central and

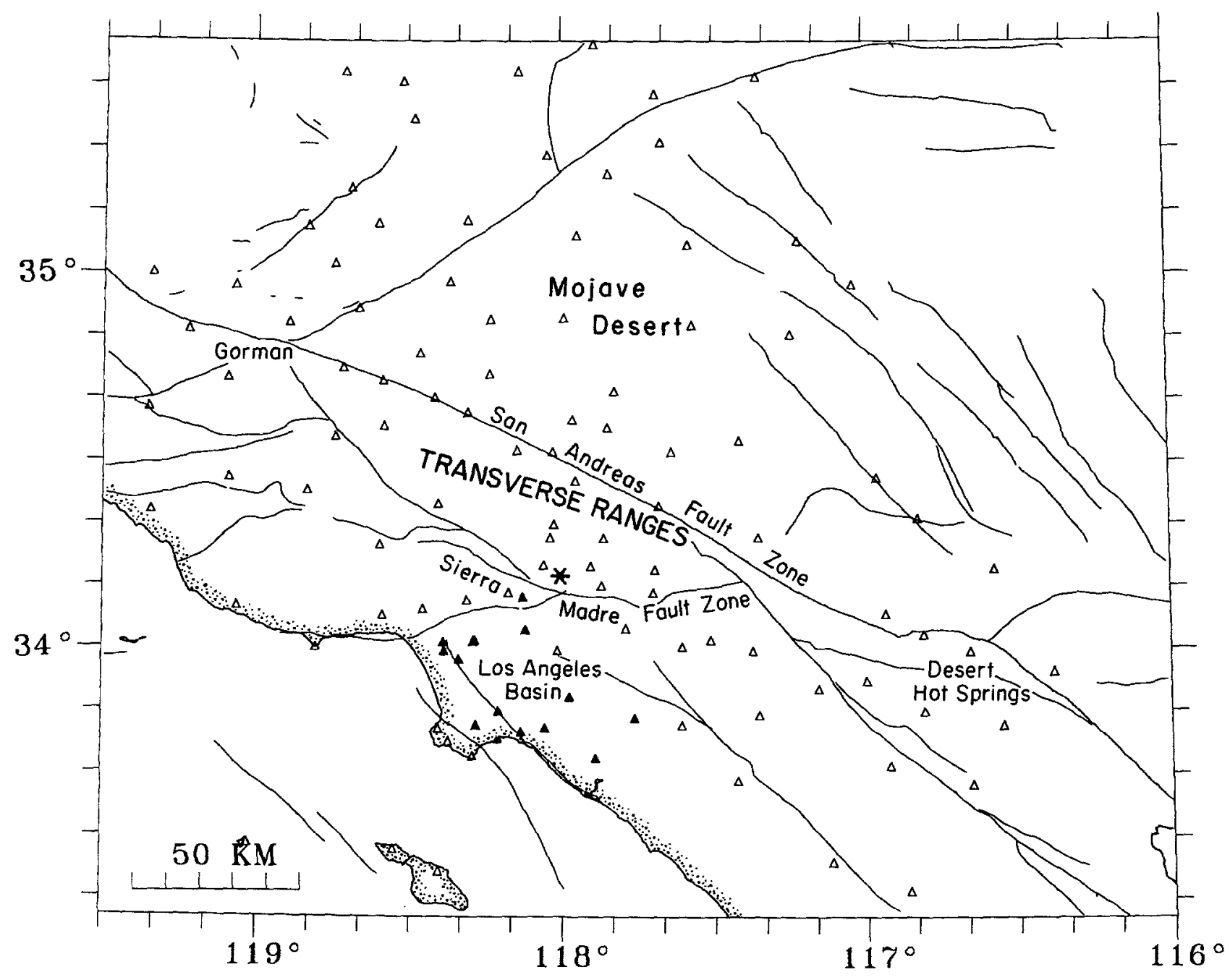

Figure 1. Map showing the location of the $M_{L}$ 5.8 Sierra Madre earthquake (star) and SCSN seismographic stations. Filled triangles represent stations assigned to the Los Angeles basin model and the open triangles represent stations assigned to the regional southern California model. 
eastern sections of the Sierra Madre fault zone is longer than about $5000 \mathrm{yr}$.

Two geological cross sections from Crook et al. (1987) are shown in Figures $4 b$ and 4c. Cross section C$\mathrm{C}^{\prime}$ (using the same labeling as Crook et al., 1987) intersects the Sierra Madre fault zone in Pasadena. The Sierra Madre fault zone is about 1 to $1.5-\mathrm{km}$ wide and follows the base of the mountains. The fault zone offsets the Pleistocene alluvial-fan sediments (Qal4) and PreCretaceous gneiss (gn) units. In cross section D-D', the fault zone has a similar width of 1 to $1.5 \mathrm{~km}$, while the change in topographic gradient across the fault zone is somewhat less. The overall surficial complexity of the
Sierra Madre fault zone makes it difficult to extrapolate the surface evidence to depth and to draw strong conclusions about geometrical shape or possible segmentation at depth from surface mapping alone.

\section{Earthquake Data and Velocity Models}

The 1991 Sierra Madre sequence was recorded by the Southern California Seismographic Network (SCSN), which is a cooperative project of the California Institute of Technology and the U.S. Geological Survey. The network is digitally recorded at 100 samples per second using CUSP event detecting software (Johnson, 1983). The

\section{Central Transverse Ranges M>1.5 1981 - August 1991}

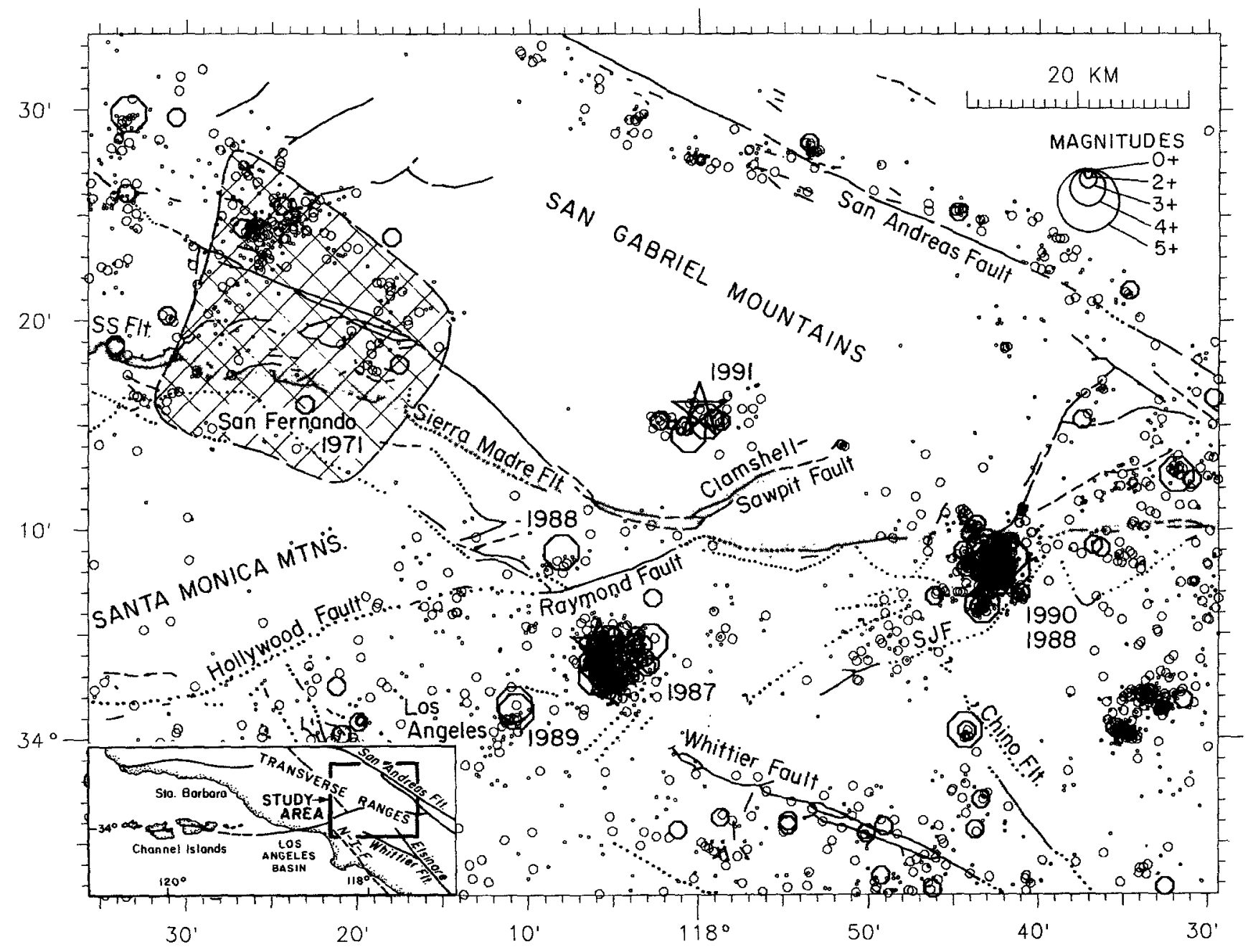

Figure 2. Map of the northern Los Angeles basin and the San Gabriel Mountains showing major faults (dotted if inferred) from Jennings (1975) and the location of earthquakes of $M>1.5$ from 1981 to August 1991 recorded by the SCSN. Earthquakes of $M_{L} \geqq 5$ are shown as stars. Dates of earthquakes $M_{L} \geqq 5$ are given. The shaded region defines the aftershock zone of the 1971 San Fernando earthquake. SS Flt, eastern end of the Santa Susanna fault. SJF, San Jose fault. 
$P$ and $S$ arrival times and $P$-wave first-motion data from SCSN were used to obtain high-quality hypocenters and focal mechanisms. Kanamori et al. (1993) determined the magnitude $\left(M_{L} 5.8\right)$ of the mainshock from TERRAscope data.

Arrival time data from the mainshock, 103 aftershocks, the 1987 Whittier Narrows blast (Hauksson and Jones, 1989), and a 1984 Azusa quarry blast were simultaneously inverted for improved hypocenters, two velocity models, and a set of station delays using the VELEST code (Roecker and Ellsworth, 1978). A separate velocity model was assigned to stations located on the sediments in the Los Angeles basin (Fig. 1). The initial models with fixed layer boundaries used by Hauksson and Jones (1989) for the 1987 Whittier sequence were used as starting models for the inversion. The final velocity models for the 1991 Sierra Madre sequence are listed in Table 1. These models reflect variations in crustal structure between the sedimentary basin and the crystalline basement of the San Gabriel Mountains. The final Sierra Madre models differ mainly in the upper $5.5 \mathrm{~km}$ of crust from the final Whittier Narrows models. This may in part be caused by different data sets and a larger number of stations located on soft basin sediments during the Whittier Narrows sequence than during the Sierra Madre sequence.

To test the location capability of the new models, we also located the 1987 Whittier Narrows and the 1984 Azusa shots and the mainshock with the standard Hadley and Kanamori (1977) model for southern California. Those locations were compared to locations obtained from the new models and their corresponding station delays. The refined shot hypocenters are within a $0.2-$ to $0.3-\mathrm{km}$ distance of the true hypocenters, as compared to a 1- to 3$\mathrm{km}$ distance for the Hadley Kanamori (1977) model, indicating that the model provides higher-quality absolute locations.

The final velocity models and delays were used as input to HYPOINVERSE (Klein, 1985) to obtain final locations for the sequence. The final locations on average have a root-mean-square (rms) residual of $0.05 \mathrm{sec}$ or less, as compared with the average rms of the catalog hypocenters of $0.2 \mathrm{sec}$. The average horizontal and vertical hypocentral uncertainties were about 0.4 and 0.6 $\mathrm{km}$, respectively.

Single-event, lower-hemisphere focal mechanisms

199| SIERRA MADRE EARTHQUAKE

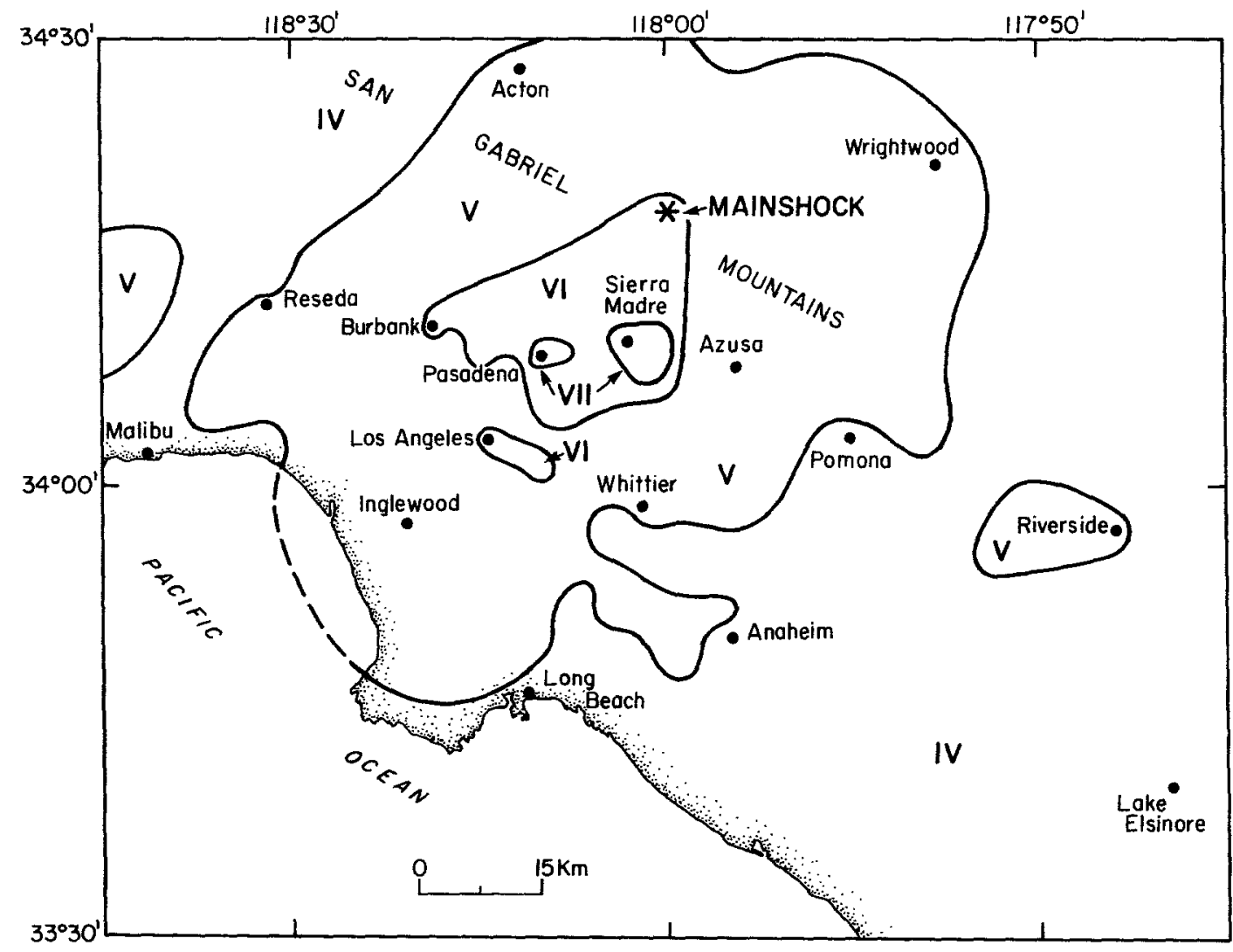

Figure 3. Isoseismal map for the Los Angeles region showing the MMI of the 1991 Sierra Madre earthquake, from Stover and Reagor (1991). 
(a)

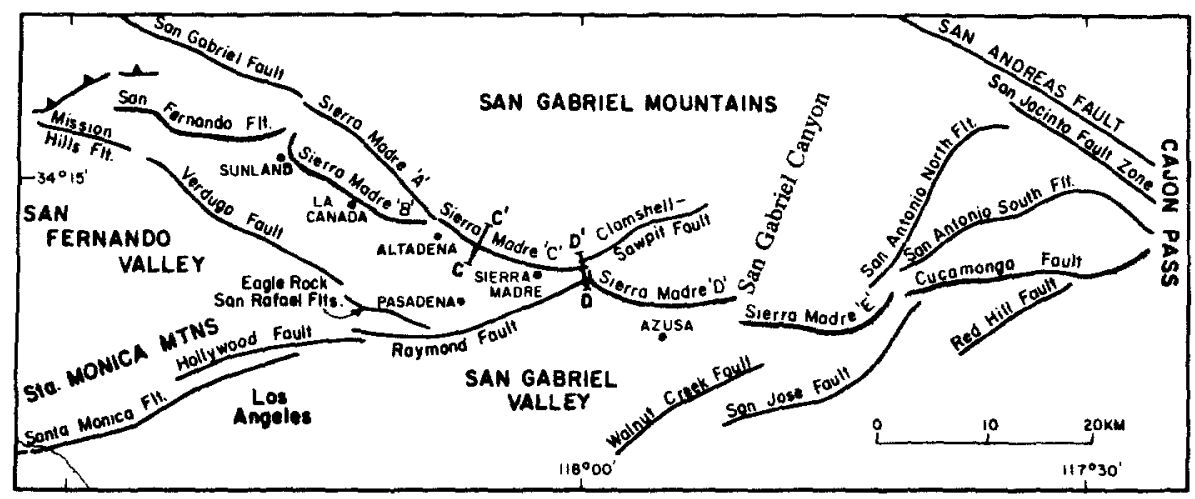

(b)

(c)
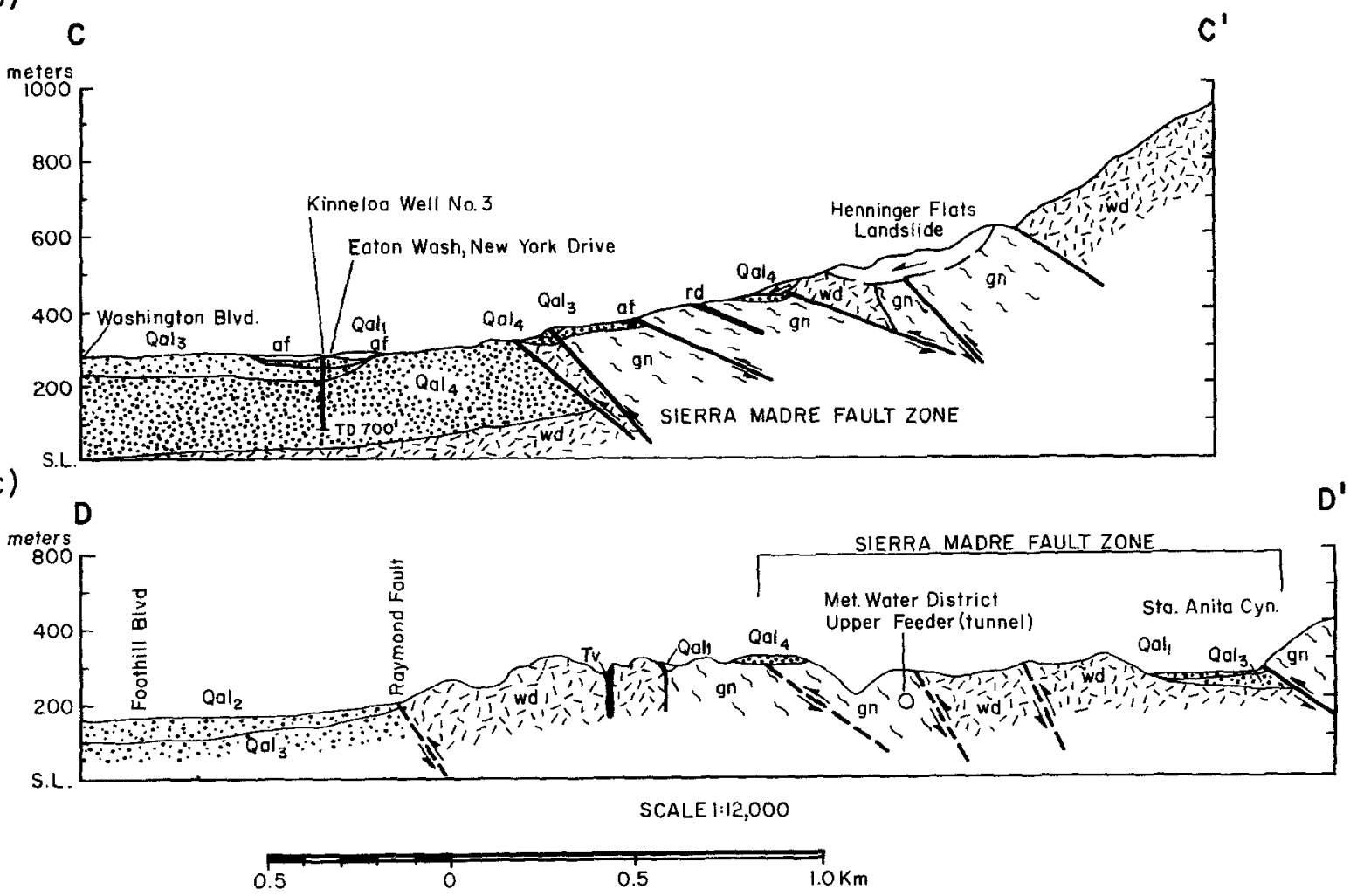

Figure 4. (a) Map of the Sierra Madre fault zone and adjacent faults, from Wesnousky (1986). (b) Geologic cross section along the line C-C' ${ }^{\prime}$ across the Sierra Madre fault zone, from Crook et al. (1987). Rock types are as follows: af, artificial fill; Qall, unit 1 Holocene white to light-gray unconsolidated fine to coarse sediments; Qa12, unit 2 Holocene gray to pale-brown unconsolidated fine to coarse sediments; Qal3, unit 3 Pleistocene yellow to yellowish-pale-brown unconsolidated fine to medium sediments; Qal4, unit 4 Pleistocene red to reddishbrown unconsolidated fine to medium sediments; gn, gneiss Pre-Cretaceous; rd, Cretaceous Rubio Diorite; wd, Cretaceous Wilson Diorite; Qalf, alluvial-fan surface; Tv, Miocene volcanic rocks. (c) Geologic cross section along the line D$\mathrm{D}^{\prime}$, from Crook et al. (1987). 
of the mainshock and 29 aftershocks are shown in Figure 5 and listed in Table 2. These were determined following Reasenberg and Oppenheimer (1985). Of the 32 aftershocks of $M>1.5$, focal mechanisms could not be determined for three events because these were immediately preceded by other aftershocks. In most cases, the nodal planes are well constrained and errors in strike, dip, and rake are usually less than $10^{\circ}$.

\section{Results}

\section{Spatial Distribution of Hypocenters}

The 1991 Sierra Madre earthquake sequence was just big enough to allow a detailed study of the fault geometry and correlation of the sequence with nearby mapped faults (Fig. 6). The nodal planes for the focal mechanism of the mainshock are as follows: strike $\mathrm{N} 62^{\circ} \mathrm{E}$, $\operatorname{dip} 50^{\circ}$, and rake $82^{\circ}$, and strike $\mathrm{N} 105^{\circ} \mathrm{W}$, dip $40^{\circ}$, and rake $100^{\circ}$. The spatial distribution of the hypocenters of the mainshock and the aftershocks and the mainshock focal mechanism suggest that the causative fault is a $50^{\circ}$ northwest-dipping thrust fault. The slip on this fault was almost pure thrust with north over south movement. Dreger and Helmberger (1991) obtained a similar focal mechanism for the mainshock with strike of $N 55^{\circ} \mathrm{E}$, dip $50^{\circ}$, and rake $74^{\circ}$ from the inversion of long-period data recorded by TERRAscope.

The mainshock and aftershocks form a distribution subparallel to the Clamshell-Sawpit fault, a splay of the Sierra Madre fault zone. The A-A' depth section (Fig. 6), taken normal to the focal plane of the mainshock, shows that most of the aftershocks are in the depth range of 9 to $14 \mathrm{~km}$ and form a north-dipping cluster. The B$\mathrm{B}^{\prime}$ cross section, taken parallel to the strike of the northdipping nodal plane of the mainshock focal mechanism, shows that most of the aftershocks are located above the mainshock hypocenter. Wald (1992), who modeled the rupture as a $12-\mathrm{km}^{2}$ area, showed that the region with no aftershocks, to the southwest of the mainshock, was a region of high slip (slip of $80 \mathrm{~cm}$ ) during the mainshock (Fig. 6c).

Table 1

$P$-Wave Velocity Models for Sierra Madre Sequence

\begin{tabular}{|c|c|c|c|c|c|}
\hline \multicolumn{3}{|c|}{ Southern California Model } & \multicolumn{3}{|c|}{ Los Angeles Basin Model } \\
\hline $\begin{array}{c}\text { Initial } \\
\text { Velocity } \\
(\mathrm{km} / \mathrm{sec})\end{array}$ & $\begin{array}{c}\text { Final } \\
\text { Velocity } \\
(\mathrm{km} / \mathrm{sec})\end{array}$ & $\begin{array}{c}\text { Depth to Top } \\
\text { of Layer } \\
(\mathrm{km})\end{array}$ & $\begin{array}{c}\text { Initial } \\
\text { Velocity } \\
(\mathrm{km} / \mathrm{sec})\end{array}$ & $\begin{array}{c}\text { Final } \\
\text { Velocity } \\
(\mathrm{km} / \mathrm{sec})\end{array}$ & $\begin{array}{l}\text { Depth to Top } \\
\text { of Layer } \\
(\mathrm{km})\end{array}$ \\
\hline 5.50 & 4.00 & 0.00 & 3.30 & 3.09 & 0.00 \\
\hline 5.50 & 5.84 & 2.00 & 4.00 & 4.38 & 2.00 \\
\hline 6.30 & 6.27 & 5.50 & 5.90 & 6.24 & 5.50 \\
\hline 6.70 & 6.48 & 16.0 & 6.50 & 6.45 & 13.0 \\
\hline 7.80 & 7.60 & 32.0 & 6.70 & 6.69 & 16.0 \\
\hline$\longrightarrow$ & - & - & 7.80 & 7.80 & 30.0 \\
\hline
\end{tabular}

\section{Temporal Distribution and Statistics}

The 1991 Sierra Madre earthquake sequence was short-lived (Fig. 7). Most of the 104 aftershocks of $M_{L}$ 1 to 4 occurred during the first $12 \mathrm{hr}$. The temporal development of activity along the fault indicates that the aftershock zone reached its final size immediately following the earthquake. The deeper aftershocks disappeared quickly and only scattered activity remained along the upper part of the aftershock zone. One large late aftershock, $M_{L} 4$, occurred 9 days following the mainshock.

The rate of aftershocks in time and magnitude space can be described by

$$
\lambda(t, M)=10^{\left[a+b\left(M_{m}-M\right)\right]}(t+c)^{-p},
$$

where $M_{m}$ is the magnitude of the mainshock, $M$ is magnitude, $t$ is time, and $a, b, c$, and $p$ are constants (Reasenberg and Jones, 1989); $b$ is the $b$ value from the Gutenberg-Richter relation, $p$ is the decay rate from Omori's law, and $a$ represents the overall productivity of the sequence. Reasenberg and Jones (1989) showed that for a suite of California aftershock sequences, these constants are normally distributed around means of $a=-1.76$, $b=0.9, c=0.05$, and $p=1.05$. The variations in these parameters between sequences can be related to tectonic regime, heat flow, and state of stress (Kisslinger and Jones, 1991). For the 1991 Sierra Madre sequence, these constants are as follows: $a=1.82 \pm 0.49, b=0.59 \pm$ $0.11, p=1.13 \pm 0.1$, and $c=0.01 \pm 0.02$. In comparison, the only anomalous constant for the Sierra Madre sequence appears to be the low $b$ value, which may be caused by the depth of the sequence or the high state of stress in the mainshock region.

\section{Relation to Surficial Faults}

The preferred nodal plane of the Sierra Madre mainshock does not connect to surficial faults in a simple manner. The dip of the preferred nodal plane of the mainshock is $50^{\circ}$, while the dip of the surface trace of the Clamshell--Sawpit fault is about $40^{\circ}$ (Crook et al., 1987). This suggests that the dip of the Clamshell-Sawpit fault may steepen with depth, as was reported for the San Fernando fault (Whitcomb et al., 1973). No aftershocks are associated with the San Gabriel fault, which is not thought to be active (Ziony and Yerkes, 1985) (Fig. 8).

To illustrate the geometrical relationship between the 1987 Whittier Narrows and the 1991 Sierra Madre earthquake sequences and nearby faults, both sequences are shown in Figure 8. The 1987 Whittier Narrows sequence was located south of the range-bounding reverse faults (Hauksson and Jones, 1989). It occurred on the $25^{\circ}$ northdipping Elysian Park concealed thrust and was not associated with surficial faults. In contrast, the 1991 Sierra Madre sequence occurred to the north, within the range- 
bounding zone of reverse faulting of the Sierra Madre fault zone.

Although the north-south distance between the two sequences is only $20 \mathrm{~km}$, they are associated with spatially separate thrust systems with different types of surficial expression. The slip along shallower dipping faults, such as occurred in the Whittier Narrows earthquake, causes only folding of the near-surface sediments (Davis et al., 1989). In contrast, seismic slip along the steeperdipping Sierra Madre fault zone has resulted in past surface rupture.

\section{Focal Mechanisms}

The focal mechanisms are plotted in map view and shown in cross section at their respective epicenters in Figure 9. Most of the focal mechanisms show thrust faulting on approximately east-northeast- or west-striking planes. In map view, two spatially separated groups of focal mechanisms can be identified, one to the east with planes striking mostly east-northeast and the other to the west with planes striking mostly to the east-west, suggesting some complexity in the faulting process. This
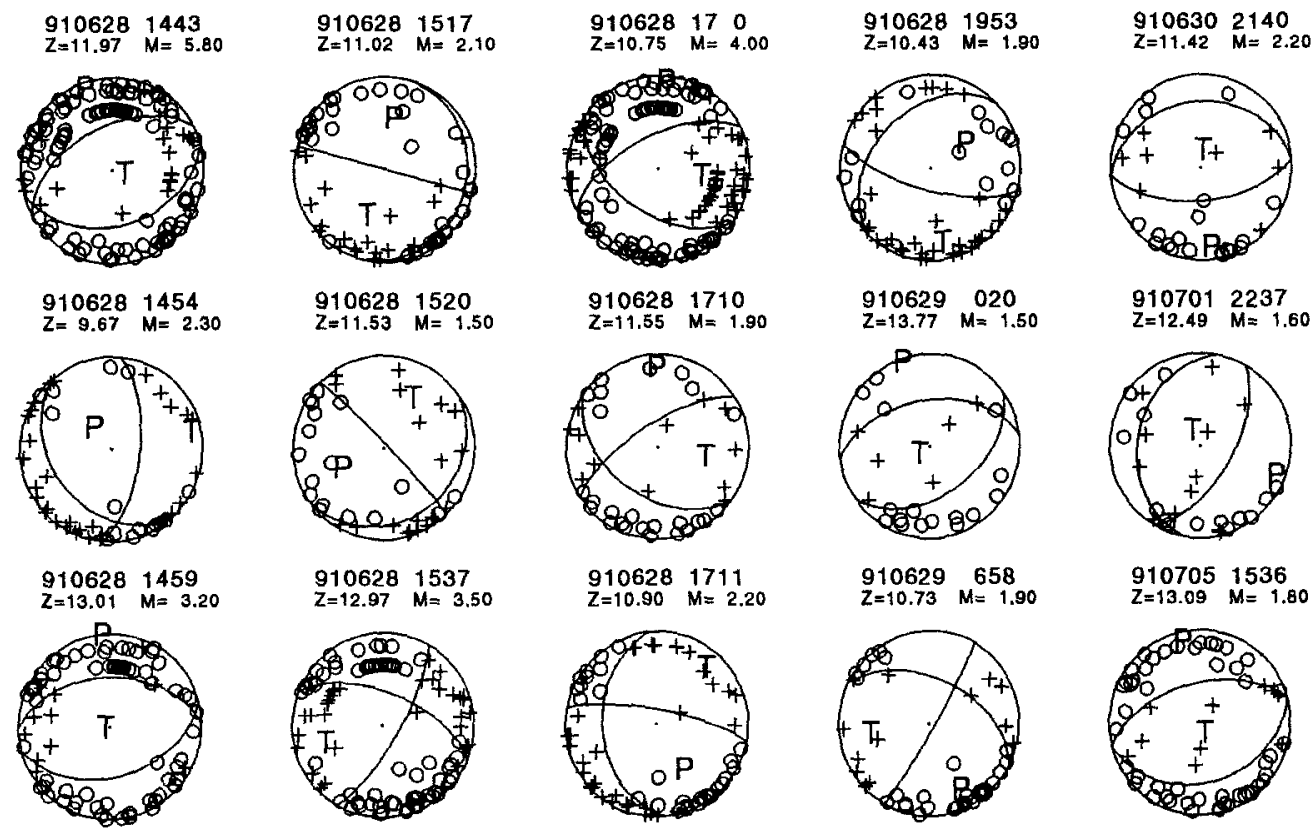

$910628 \quad 15 \quad 4 \quad C$
$Z=7.21 \quad M=2.00$
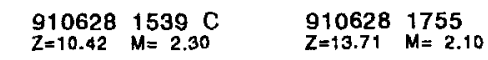

$910630 \quad 214$
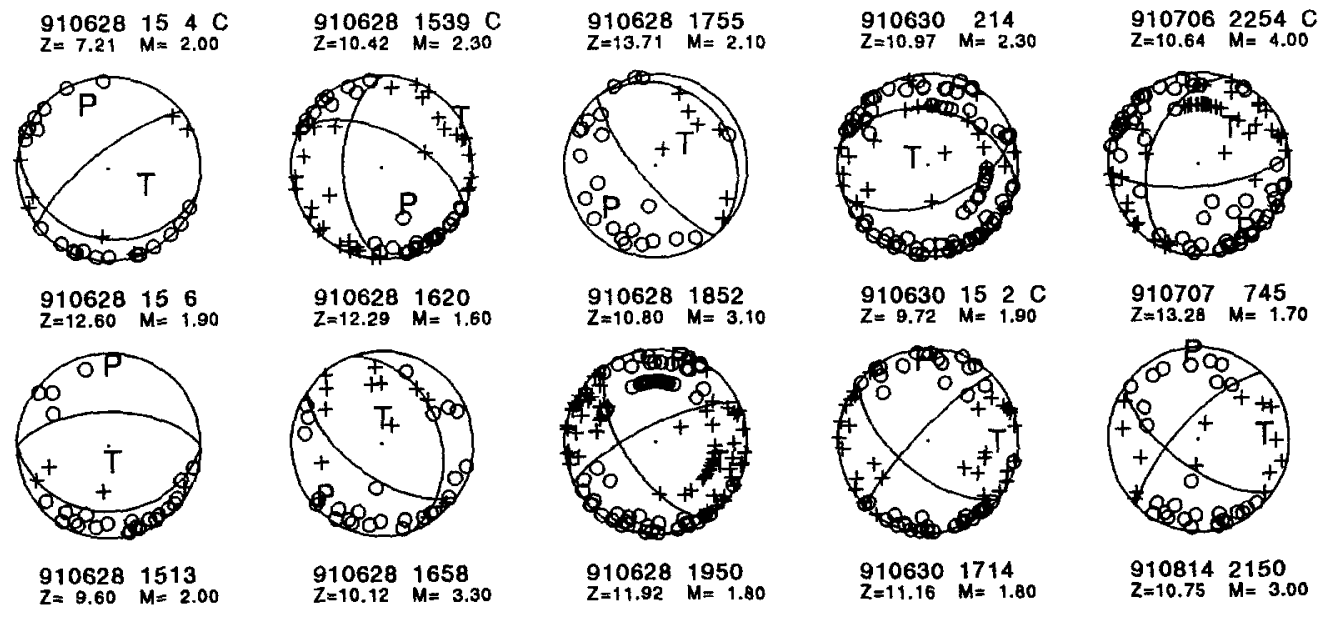

$\underset{Z=10.75}{910814} \underset{M=3.00}{2150}$
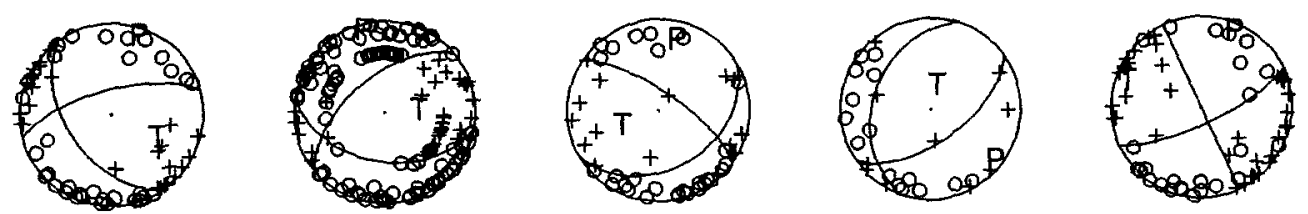

Figure 5. Single-event, lower-hemisphere focal mechanisms for $M_{L} \geqq 1.5$ mainshock-aftershocks of the 1991 Sierra Madre earthquake sequence. Compressional first motions are shown by pluses and dilatational first motions by open circles. 
variation in the mechanisms is probably not statistically significant. The two cross sections $\mathrm{A}^{-\mathrm{A}^{\prime}}$ and $\mathrm{B}-\mathrm{B}^{\prime}$ in Figure 9 show the depth distribution of these two groups, where the group to the west has a better-defined dip. Because no shallow aftershocks occurred, it is not possible to associate these distributions to surface faults.

Several aftershocks occurred between and along the edges of the two thrust planes, indicating secondary tear faulting. A few of these events show strike-slip faulting on northwest- or northeast-striking planes. Three events have one subhorizontal nodal plane and four events exhibited normal faulting. None of these tear faults can be associated with mapped surficial faults.

\section{Discussion}

\section{State of Stress}

The focal mechanism data were inverted for the orientation of the principal stress axes and a measure of their relative magnitude $(\phi)$ following Michael (1984). The inversion minimizes the misfit angle between the direction of the shear stress on the fault plane and the observed slip direction on that plane determined from the focal mechanism. The inversion technique assumes that the regional stress field is a constant tensor, all slip events are independent, and the magnitude of the tangential traction applied to each fault plane is similar. The $\phi$ value is defined as

$$
\phi=\frac{\left(\sigma_{2}-\sigma_{3}\right)}{\left(\sigma_{1}-\sigma_{3}\right)}
$$

where $\sigma_{1}, \sigma_{2}$, and $\sigma_{3}$ are the maximum, intermediate, and minimum principal compressive stresses, respectively. One plane must be selected from each focal mechanism as the actual fault plane (Michael, 1987a). The bootstrap technique used for calculating the $95 \%$ confidence limits accounts for incorrectly picked planes by assuming that some percentage of the planes are picked incorrectly (Michael, 1987b). Because the causative fault is well defined in this case, we assume only $10 \%$ are incorrect.

To study the regional state of stress that has generated the recent increase in seismicity in the northern

Table 2

Locations and Focal Mechanisms of The 1991 Sierra Madre Sequence

\begin{tabular}{|c|c|c|c|c|c|c|c|c|c|}
\hline \multirow{2}{*}{$\begin{array}{l}\text { Origin } \\
\text { (Date) }\end{array}$} & \multirow{2}{*}{$\begin{array}{c}\text { Time } \\
\text { (UTC) }\end{array}$} & \multirow{2}{*}{$\begin{array}{l}\text { Latitude } \\
\text { (N) }\end{array}$} & \multirow{2}{*}{$\begin{array}{c}\text { Longitude } \\
\text { (W) }\end{array}$} & \multirow{2}{*}{$\begin{array}{c}\text { Depth. } \\
\text { (km) }\end{array}$} & \multirow{2}{*}{$\begin{array}{l}\text { Magnitude } \\
\left(M_{L}\right)\end{array}$} & \multicolumn{3}{|c|}{ Focal Mechanisms } & \multirow{2}{*}{$\begin{array}{l}\text { Number } \\
\text { of First } \\
\text { Motions }\end{array}$} \\
\hline & & & & & & Ddir & Dip & Rake & \\
\hline 28 June 1991 & $14: 43$ & $34^{\circ} 15.54^{\prime}$ & $118^{\circ} 00.06^{\prime}$ & 11.97 & 5.8 & $332^{\circ}$ & $50^{\circ}$ & $82^{\circ}$ & 123 \\
\hline 28 June 1991 & $14: 54$ & $34^{\circ} 14.51^{\prime}$ & $118^{\circ} 00.91^{\prime}$ & 9.67 & 2.3 & $96^{\circ}$ & $64^{\circ}$ & $-66^{\circ}$ & 46 \\
\hline 28 June 1991 & $14: 59$ & $34^{\circ} 14.97^{\prime}$ & $118^{\circ} 02.37^{\prime}$ & 13.01 & 3.2 & $359^{\circ}$ & $46^{\circ}$ & $100^{\circ}$ & 83 \\
\hline 28 June 1991 & $15: 04$ & $34^{\circ} 14.68^{\prime}$ & $118^{\circ} 01.97^{\prime}$ & 7.21 & 2.0 & $322^{\circ}$ & $74^{\circ}$ & $70^{\circ}$ & 28 \\
\hline 28 June 1991 & $15: 06$ & $34^{\circ} 14.86^{\prime}$ & $118^{\circ} 02.18^{\prime}$ & 12.6 & 1.9 & $0^{\circ}$ & $60^{\circ}$ & $90^{\circ}$ & 29 \\
\hline 28 June 1991 & $15: 13$ & $34^{\circ} 14.84^{\prime}$ & $118^{\circ} 00.80^{\prime}$ & 9.60 & 2.0 & $345^{\circ}$ & $67^{\circ}$ & $44^{\circ}$ & 63 \\
\hline 28 June 1991 & $15: 17$ & $34^{\circ} 15.45^{\prime}$ & $118^{\circ} 00.56^{\prime}$ & 11.02 & 2.1 & $15^{\circ}$ & $90^{\circ}$ & $100^{\circ}$ & 58 \\
\hline 28 June 1991 & $15: 20$ & $34^{\circ} 16.04^{\prime}$ & $117^{\circ} 58.99^{\prime}$ & 11.53 & 1.5 & $46^{\circ}$ & $87^{\circ}$ & $-70^{\circ}$ & 37 \\
\hline 28 June 1991 & $15: 37$ & $34^{\circ} 14.86^{\prime}$ & $117^{\circ} 58.98^{\prime}$ & 12.97 & 3.5 & $21^{\circ}$ & $61^{\circ}$ & $163^{\circ}$ & 99 \\
\hline 28 June 1991 & $15: 39$ & $34^{\circ} 14.77^{\prime}$ & $117^{\circ} 58.63^{\prime}$ & 10.42 & 2.3 & $26^{\circ}$ & $58^{\circ}$ & $-138^{\circ}$ & 64 \\
\hline 28 June 1991 & $16: 20$ & $34^{\circ} 15.15^{\prime}$ & $118^{\circ} 02.26^{\prime}$ & 12.29 & 1.6 & $71^{\circ}$ & $35^{\circ}$ & $121^{\circ}$ & 37 \\
\hline 28 June 1991 & $16: 58$ & $34^{\circ} 14.99^{\prime}$ & $117^{\circ} 59.42^{\prime}$ & 10.12 & 3.3 & $320^{\circ}$ & $57^{\circ}$ & $57^{\circ}$ & 146 \\
\hline 28 June 1991 & $17: 00$ & $34^{\circ} 14.81^{\prime}$ & $117^{\circ} 59.89^{\prime}$ & 10.75 & 4.0 & $333^{\circ}$ & $60^{\circ}$ & $48^{\circ}$ & 151 \\
\hline 28 June 1991 & $17: 10$ & $34^{\circ} 15.38^{\prime}$ & $118^{\circ} 02.52^{\prime}$ & 11.55 & 1.9 & $327^{\circ}$ & $69^{\circ}$ & $49^{\circ}$ & 37 \\
\hline 28 June 1991 & $17: 11$ & $34^{\circ} 14.38^{\prime}$ & $118^{\circ} 01.12^{\prime}$ & 10.90 & 2.2 & $11^{\circ}$ & $77^{\circ}$ & $-128^{\circ}$ & 61 \\
\hline 28 June 1991 & $17: 55$ & $34^{\circ} 15.17^{\prime}$ & $118^{\circ} 02.58^{\prime}$ & 13.71 & 2.1 & $50^{\circ}$ & $15^{\circ}$ & $90^{\circ}$ & 29 \\
\hline 28 June 1991 & $18: 52$ & $34^{\circ} 14.63^{\prime}$ & $118^{\circ} 00.83^{\prime}$ & 10.80 & 3.1 & $335^{\circ}$ & $75^{\circ}$ & $30^{\circ}$ & 142 \\
\hline 28 June 1991 & $19: 50$ & $34^{\circ} 14.71^{\prime}$ & $118^{\circ} 02.42^{\prime}$ & 11.92 & 1.8 & $35^{\circ}$ & $73^{\circ}$ & $121^{\circ}$ & 44 \\
\hline 28 June 1991 & $19: 53$ & $34^{\circ} 14.65^{\prime}$ & $118^{\circ} 00.64^{\prime}$ & 10.43 & 1.9 & $316^{\circ}$ & $35^{\circ}$ & $-144^{\circ}$ & 50 \\
\hline 29 June 1991 & $00: 20$ & $34^{\circ} 15.77^{\prime}$ & $118^{\circ} 00.84^{\prime}$ & 13.77 & 1.5 & $352^{\circ}$ & $48^{\circ}$ & $109^{\circ}$ & 22 \\
\hline 29 June 1991 & $6: 58$ & $34^{\circ} 16.10^{\prime}$ & $117^{\circ} 58.35^{\prime}$ & 10.73 & 1.9 & $120^{\circ}$ & $85^{\circ}$ & $40^{\circ}$ & 43 \\
\hline 30 June 1991 & $2: 14$ & $34^{\circ} 14.42^{\prime}$ & $118^{\circ} 01.77^{\prime}$ & 10.97 & 2.3 & $12^{\circ}$ & $40^{\circ}$ & $116^{\circ}$ & 104 \\
\hline 30 June 1991 & $15: 02$ & $34^{\circ} 15.50^{\prime}$ & $117^{\circ} 58.49^{\prime}$ & 9.72 & 1.9 & $315^{\circ}$ & $80^{\circ}$ & $30^{\circ}$ & 77 \\
\hline 30 June 1991 & $17: 14$ & $34^{\circ} 14.89^{\prime}$ & $118^{\circ} 01.70^{\prime}$ & 11.16 & 1.8 & $289^{\circ}$ & $35^{\circ}$ & $59^{\circ}$ & 25 \\
\hline 30 June 1991 & $21: 40$ & $34^{\circ} 14.66^{\prime}$ & $118^{\circ} 01.78^{\prime}$ & 11.42 & 2.2 & $355^{\circ}$ & $30^{\circ}$ & $90^{\circ}$ & 28 \\
\hline 1 July 1991 & $22: 37$ & $34^{\circ} 14.70^{\prime}$ & $118^{\circ} 02.65^{\prime}$ & 12.49 & 1.6 & $281^{\circ}$ & $31^{\circ}$ & $73^{\circ}$ & 26 \\
\hline 5 July 1991 & $15: 36$ & $34^{\circ} 15.10^{\prime}$ & $118^{\circ} 01.89^{\prime}$ & 13.09 & 1.8 & $345^{\circ}$ & $55^{\circ}$ & $90^{\circ}$ & 59 \\
\hline 6 July 1991 & $22: 54$ & $34^{\circ} 14.33^{\prime}$ & $118^{\circ} 00.75^{\prime}$ & 10.64 & 4.0 & $287^{\circ}$ & $44^{\circ}$ & $29^{\circ}$ & 109 \\
\hline 7 July 1991 & $7: 45$ & $34^{\circ} 15.10^{\prime}$ & $118^{\circ} 02.52^{\prime}$ & 13.28 & 1.7 & $314^{\circ}$ & $72^{\circ}$ & $26^{\circ}$ & 42 \\
\hline 14 August 1991 & $21: 50$ & $34^{\circ} 14.71^{\prime}$ & $117^{\circ} 57.42^{\prime}$ & 10.75 & 3.0 & $65^{\circ}$ & $90^{\circ}$ & $165^{\circ}$ & 60 \\
\hline
\end{tabular}


Sierra Madre 28 June - 15 August 1991

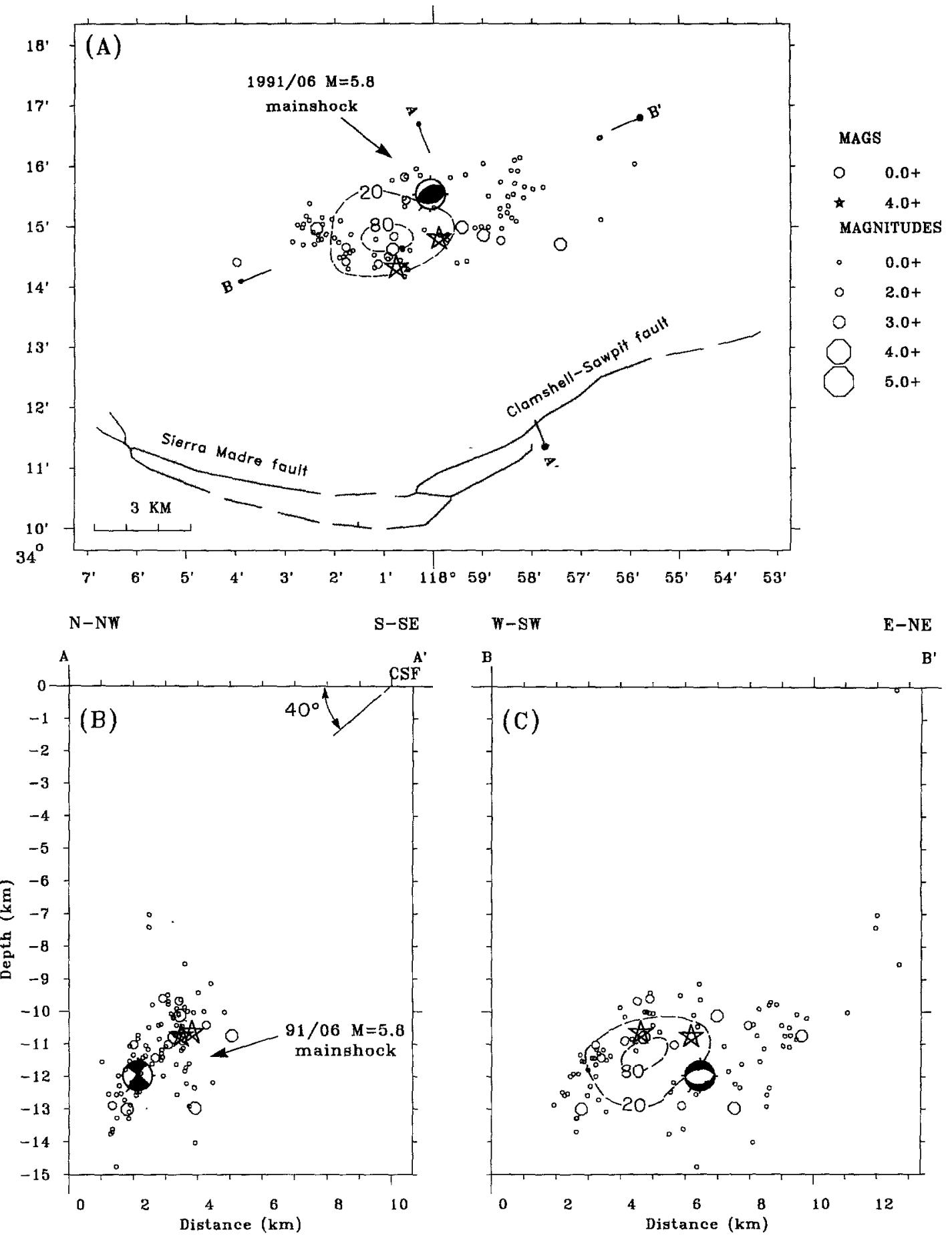

Figure 6. The mainshock-aftershock sequence of the 1991 Sierra Madre earthquake recorded by the SCSN. (a) Map showing earthquake epicenters and active faults (dotted or dashed where inferred) from Jennings (1975) and focal mechanism of the mainshock. Also shown are end points $\mathrm{A}-\mathrm{A}^{\prime}$ and $\mathrm{B}-\mathrm{B}^{\prime}$. A contour outlining the area of mainshock slip of $\geqq 20 \mathrm{~cm}$ from Wald (1992) is also shown. (b) Earthquake hypocenters projected onto the $\mathrm{A}-\mathrm{A}^{\prime}$ plane, taken approximately normal to the north-dipping nodal plane in the mainshock focal mechanism. Dashed line indicates a possible depth projection of the Clamshell-Sawpit fault (CSF). (c) Earthquake hypocenters projected onto the B-B' plane, taken approximately parallel to the strike of the north-dipping nodal plane in the mainshock focal mechanism. Contours outlining the area of mainshock slip of $\geqq 20 \mathrm{~cm}$ and $\geqq 60$ $\mathrm{cm}$ from Wald (1992) are also shown. 
Los Angeles basin and the central Transverse Ranges, stress inversions have been done for five mainshock-aftershock sequences. The state of stress was determined using focal mechanisms from Whitcomb et al. (1973) and corresponding nodal planes selected by Gephart and Forsyth (1984) for the 1971 San Fernando sequence. The focal mechanisms data and preferred planes are from Hauksson and Jones (1989) for the 1987 Whittier Narrows earthquake. The 1988 Pasadena focal mechanism data are from Jones et al. (1990) and Ma and Kanamori (1991). The lack of aftershocks makes the Pasadena earthquake the least well-determined stress state and is only included here for completeness. The 1990 Upland focal mechanisms data and the selected nodal planes are from Hauksson and Jones (1991). The 1991 Sierra Madre data are from this study. The selected planes for each sequence are shown in Figure 10a.

The stress directions along with the $95 \%$ confidence limits for the five mainshocks are shown in Figure 10b and are listed in Table 3. The preferred nodal plane, which is the mainshock rupture plane, and the slip vector from each of the mainshocks are also plotted. The average misfit angles range from $13^{\circ}$ to $36^{\circ}$, which is similar to what is observed for stress inversions of the background seismicity (Hauksson, 1990). The $\phi$ values ranged from 0.3 to 0.5 , indicating that all the principal stresses are of different size. The stress states for the 1971 San Fernando and the 1987 Whittier Narrows aftershock sequences are similar to the stress state derived from the same data set by Gephart and Forsyth (1984) and Michael (1991). The state of stress is similar for all of the sequences, except for the minimum principal stress and intermediate principal stress directions, which alternate depending on whether the stress state is strike-slip or reverse faulting.

The stress state deduced from these mainshock-aftershock sequences is very similar to the background stress state determined by Hauksson (1990), indicating that a similar stress state is present during the background seismicity and during the aftershocks of moderate-sized

\section{Sierra Madre Earthquake Sequence}

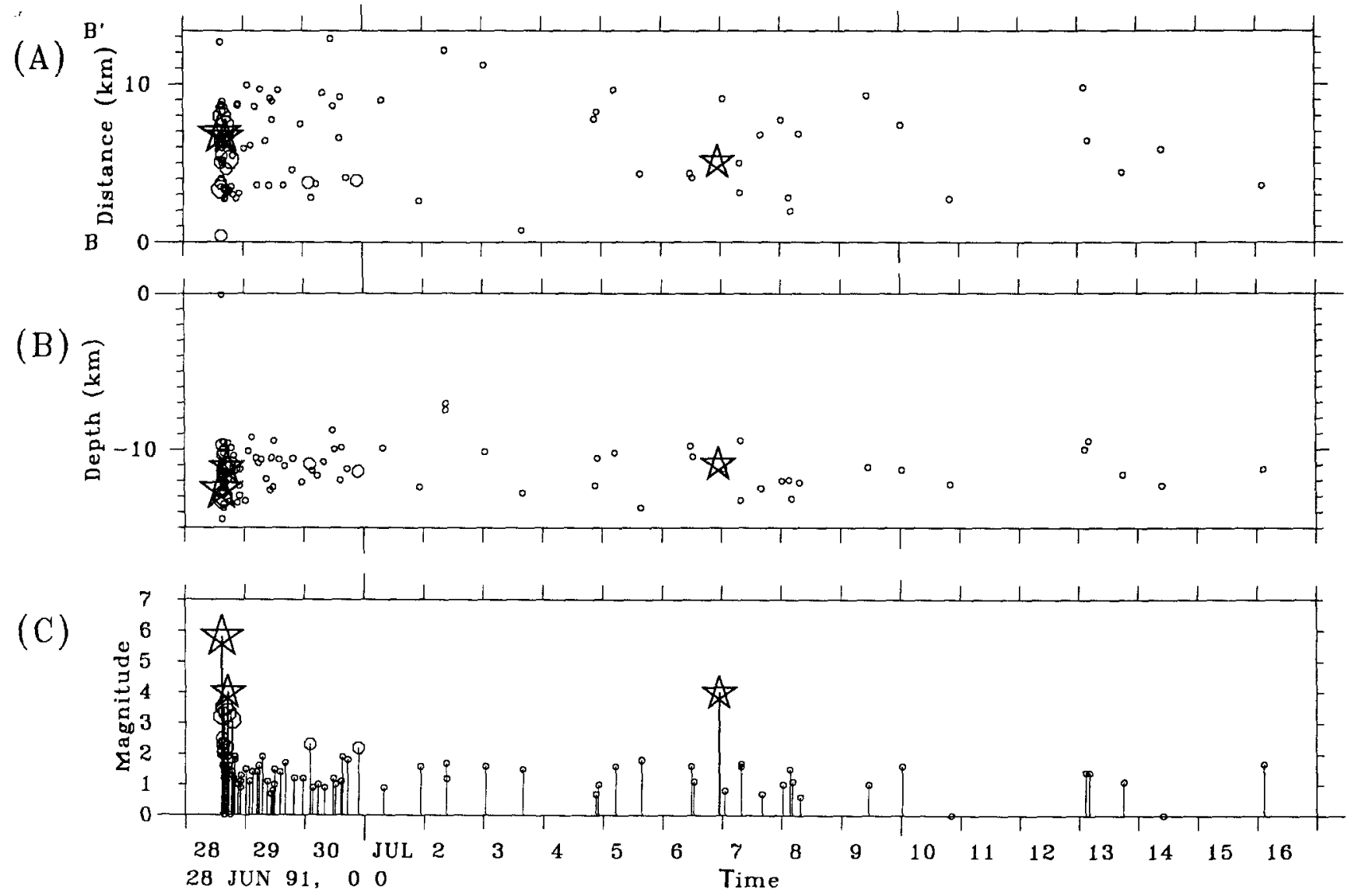

Figure 7. Temporal development of the 1991 Sierra Madre earthquake sequence. (a) Earthquake hypocenters projected on a line B-B' parallel to the northdipping nodal plane in the mainshock focal mechanism (Fig. 6), shown as a function of time. (b) Earthquake depths as a function of time. (c) Earthquake magnitudes as a function of time. 


\section{Whittier Narrows 1987 and Sierra Madre 1991}
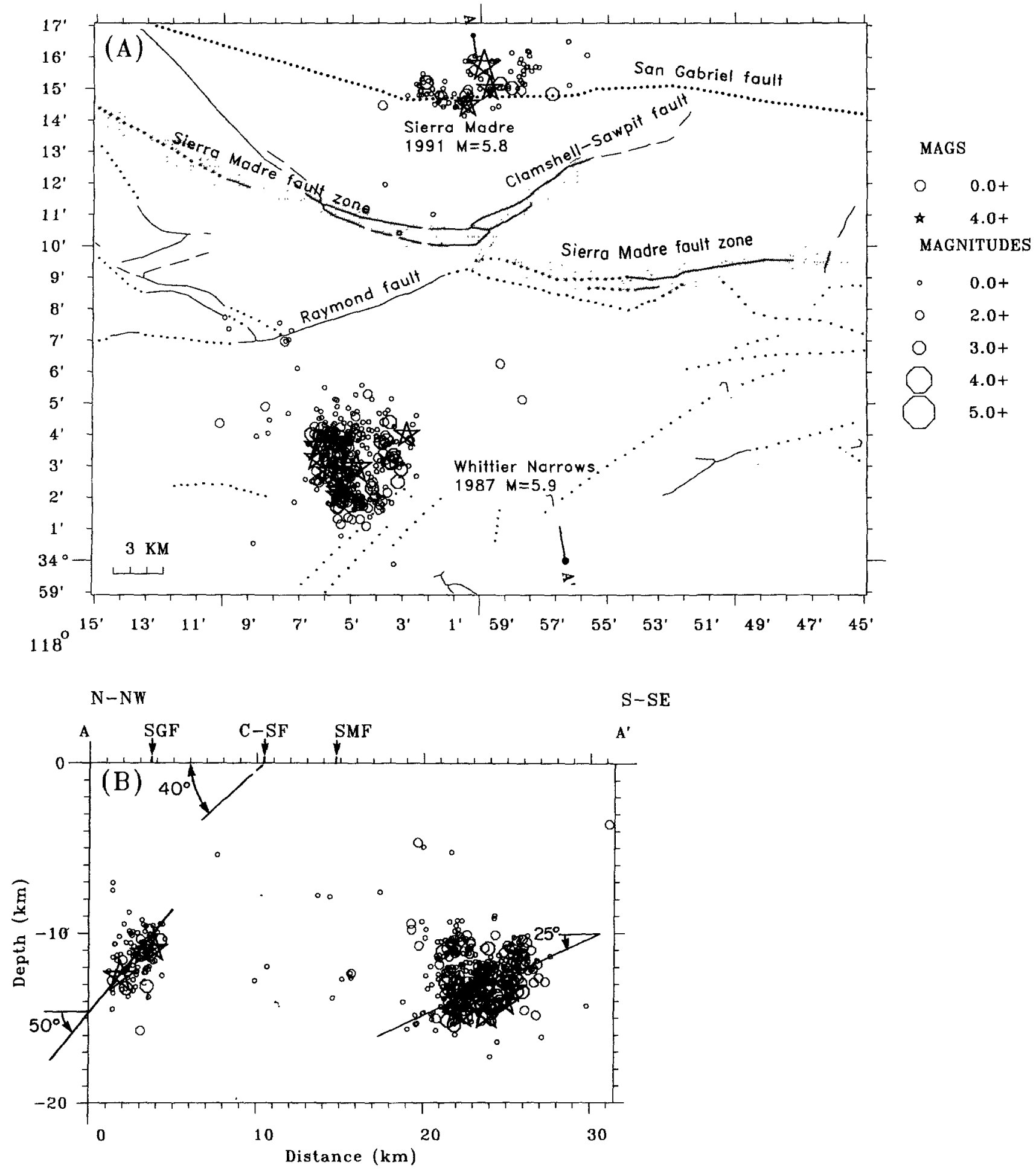

Figure 8. Comparison of the 1987 Whittier Narrows and the 1991 Sierra Madre earthquake sequence. (a) Map showing earthquake epicenters from the two sequences and active faults. The Sierra Madre fault zone is shaded for clarity. (b) North-south cross section showing the depth distribution of the two sequences and surficial dip of the Clamshell-Sawpit fault (CSF). The dips of the nodal plane of the mainshock focal mechanism are also shown. SMF, Sierra Madre fault zone. SGF, San Gabriel fault. 


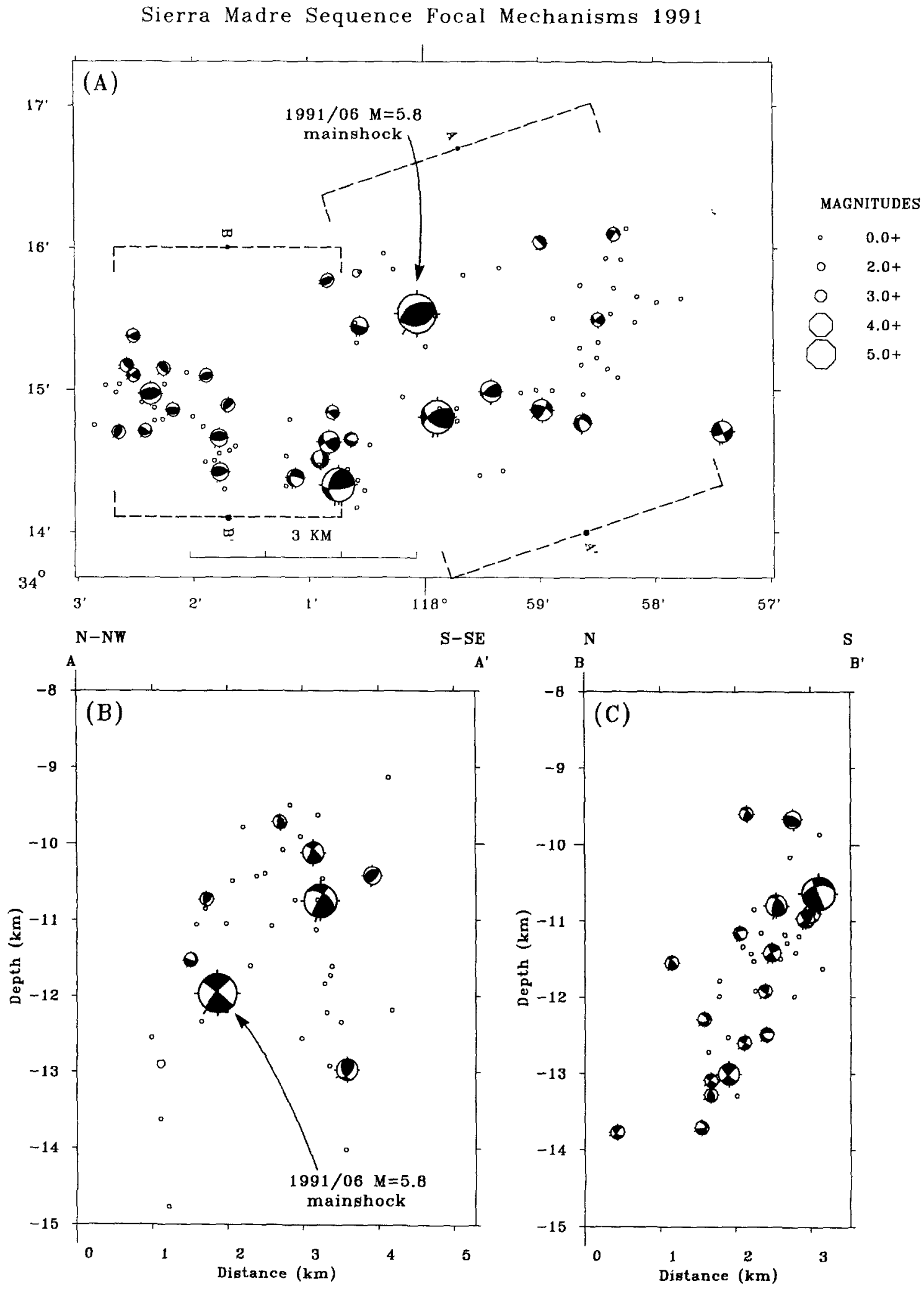

Figure 9. Single-event focal mechanisms of $M_{L} \geqq 1.5$ earthquakes of the 1991 Sierra Madre sequence. Open circle symbols represent aftershocks for which no focal mechanisms are available. (a) Map of lower hemisphere, focal mechanisms. End points $A-A^{\prime}$ and $B-B^{\prime}$ are also shown. (b) Depth cross section of the focal mechanisms projected onto the line $A-A^{\prime}$. (c) Depth cross section of the focal mechanisms projected onto the line $B-\mathrm{B}^{\prime}$. 
Central Transverse Ranges

(a) Stereonets: Nodal Planes Used in Stress Inversion

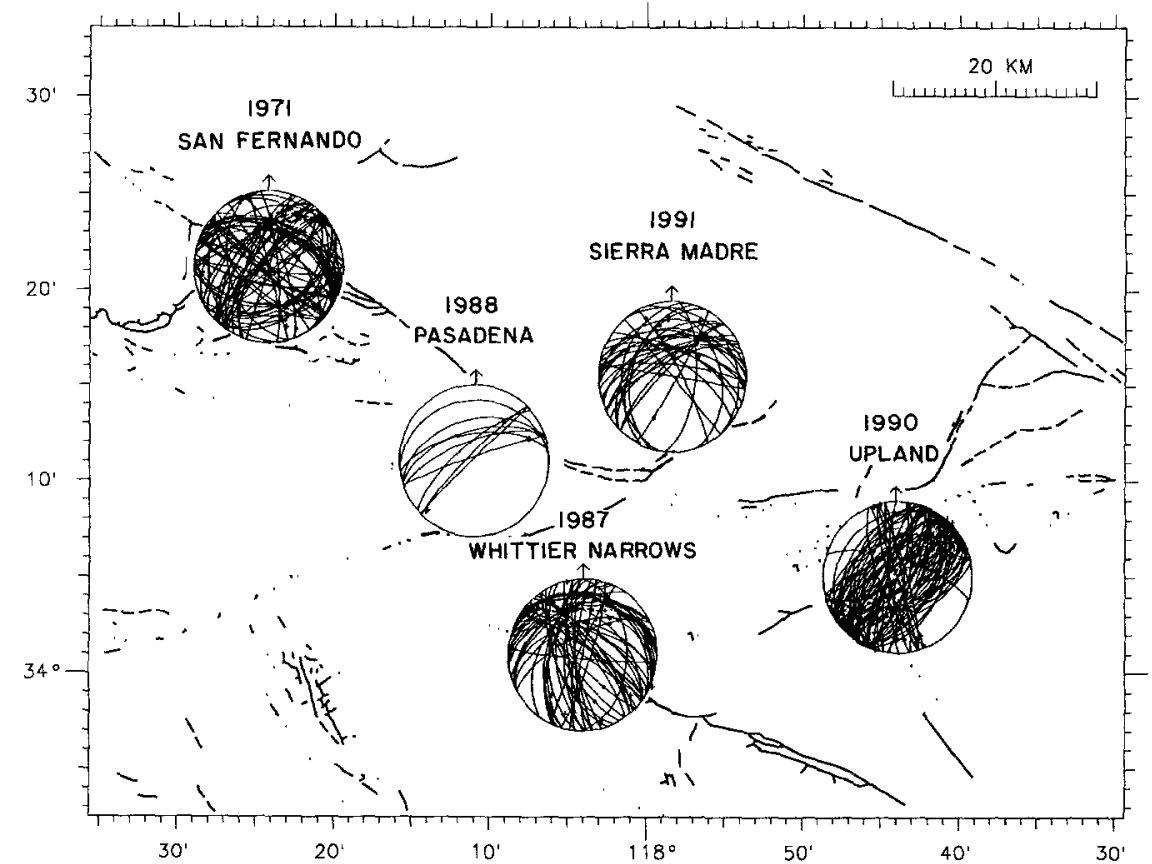

Central Transverse Ranges

(b) Stereonets: Stress Field From Sequences

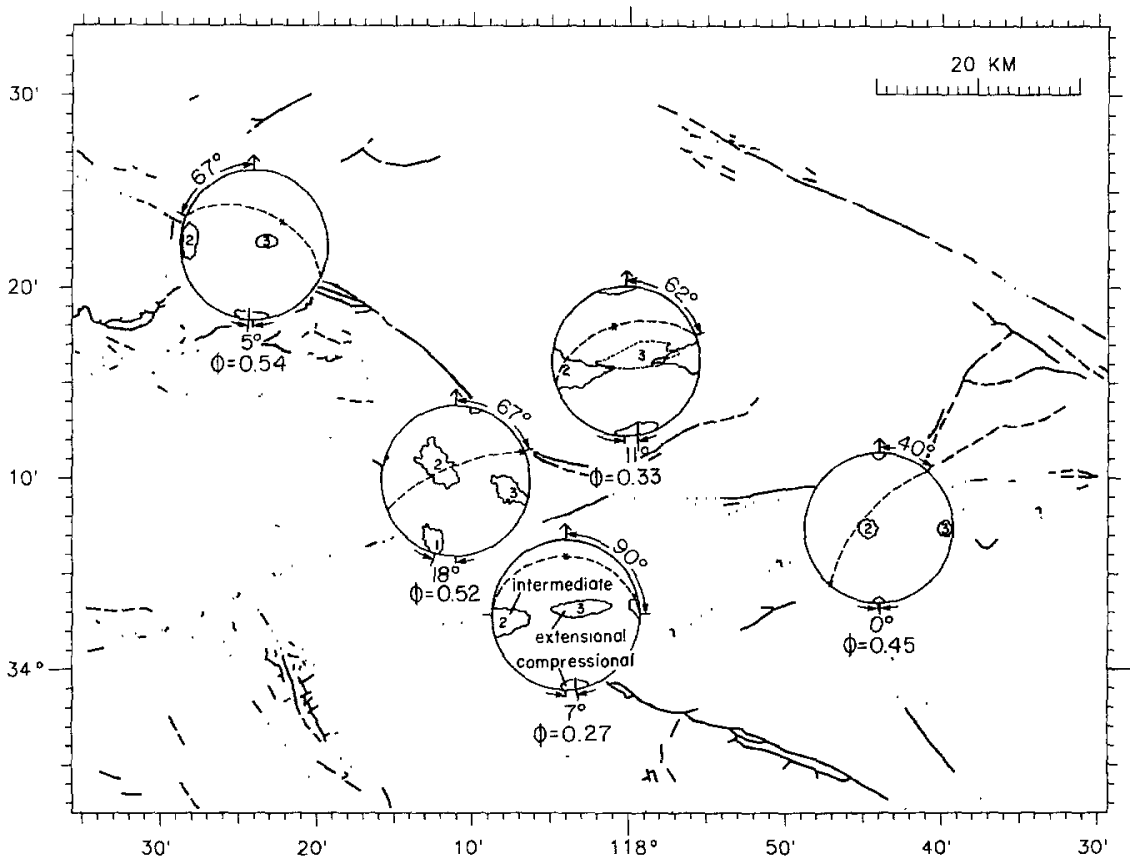

Figure 10. (a) Stereonet projections of the preferred fault planes from focal mechanisms of the 1971 San Fernando, 1987 Whittier Narrows, 1988 Pasadena, 1990 Upland, and 1991 Sierra Madre sequences. (b) The results of the stress inversion showing the $95 \%$ confidence limits of the directions of the three principal stresses, presuming that $10 \%$ of the nodal planes are picked incorrectly, indicated with solid, long, or short dashed lines; 1,2 , and 3 are the maximum, intermediate, and minimum principal stress axes. The nodal plane (dashed line) of each of the mainshocks, including slip direction, is also shown. The value of $\phi$ is also indicated. 
earthquakes. This observation suggests that these earthquakes are not large enough to release significant tectonic stress in the crustal volume where the aftershocks occurred. In comparison, during the $1989 M_{S} 7.1$ Loma Prieta and $1992 M_{w} 7.3$ Landers earthquakes, where the slip exceeded several meters, the stress directions changed and it was not possible to explain the pattern of aftershock focal mechanisms with one stress tensor (Michael et al., 1990; Hauksson, 1994).

\section{Depth Configuration}

The 1991 Sierra Madre sequence has provided a new window on the geometrical configuration of the fault zone at depth. Although this sequence occurred in a small depth range of 12 to $16 \mathrm{~km}$, it suggests that the dip of the Clamshell-Sawpit fault is $40^{\circ}$ from the surface to depths of $10 \mathrm{~km}$, where the dip may steepen to $50^{\circ}$. To the west in the San Fernando area, the fault dips at about $50^{\circ}$ in the depth range of 5 to $15 \mathrm{~km}$; at depths shallower than $5 \mathrm{~km}$ the dip is approximately $30^{\circ}$ (Whitcomb et al., 1973).

The 1971 San Fernando aftershock zone was $22-\mathrm{km}$ long and revealed the geometrical configuration of the Santa Susanna and the Sierra Madre fault zones as these merge along the southern edge of the range (Fig. 2). The Sierra Madre earthquake aftershock zone was $8-\mathrm{km}$ long and has illuminated a small section of the frontal faults that was previously seismically quiescent. The Sierra Madre earthquake occurred close to where the eastnortheast-striking Clamshell-Sawpit and Raymond faults join the Sierra Madre fault from the northeast and southwest, respectively. The Sierra Madre earthquake only broke a small segment of the Sierra Madre fault zone at depth, and long segments of the fault zone that are capable of generating large damaging earthquakes (Ziony and Yerkes, 1985; Crook et al., 1987) still remain seismically quiescent.

The segmentation of the Sierra Madre fault zone shown in Figure 11 is from Wesnousky (1986). He divided the fault zone into eight segments based on data and interpretations by Proctor et al. (1972), Ehlig (1975), and Crook et al. (1987). Segment Sierra Madre A as defined by Wesnousky (1986) (see also Fig. 4a) is actually a continuation of the south fork of the San Gabriel fault. It was called the Vasquez fault by Proctor $e t$ al. (1972). Furthermore, it parallels the Sierra Madre B segment. It is thus assumed to be the same segment as Sierra Madre B in this article.

Using the depth distribution of aftershocks of the 1971 San Fernando and the 1991 Sierra Madre earthquakes, approximate depth contours for the Sierra Madre fault zone are drawn schematically in Figure 11. These contours give some idea of how these segments may extend to depth below the range and suggest that the seven segments range in depth from the surface to about 23 to 28 $\mathrm{km}$. Only the 1971 San Fernando segment has had surface rupture during historic times, while the ClamshellSawpit segment was only partially ruptured at depth during the 1991 Sierra Madre earthquake.

\section{Regional Tectonics}

The Sierra Madre earthquake was caused by thrust faulting that uplifted the southern edge of San Gabriel Mountains directly above the hypocenter by less than 1 cm (Hudnut et al., 1991; Zumberge et al., 1991; Wald, 1992). In comparison, the southern edge of the San Gabriel Mountains was uplifted as much as 2 meters in the 1971 San Fernando earthquake (Savage et al., 1975). This ongoing uplift, which began a few million years ago, is an expression of the convergence between the North American and Pacific plates along the "big bend" in the San Andreas fault (Ehlig, 1981). The dip of the Sierra Madre fault zone, which ranges from $30^{\circ}$ to $50^{\circ}$, can only account for the uplift along the southern edge of the mountains. It does not account for the uplift of the interior and northern margin of the mountains, which may be caused by broad arching of the whole central Transverse Ranges (Ehlig, 1981).

The spatial relationship between regional tectonic structures and the three most recent moderate-sized

Table 3

Mainshock Focal Mechanisms and Stress Inversion Results

\begin{tabular}{|c|c|c|c|c|c|c|c|c|c|c|c|c|c|}
\hline \multirow[b]{2}{*}{ Sequence } & \multicolumn{3}{|c|}{$\begin{array}{c}\text { Mainshock } \\
\text { Focal Mechanism }\end{array}$} & \multirow{2}{*}{$\begin{array}{c}\text { Number } \\
\text { of Planes }\end{array}$} & \multirow[b]{2}{*}{$\phi$} & \multicolumn{2}{|c|}{$\begin{array}{c}\text { Maximum } \\
\text { Principal } \\
\text { Stress }\end{array}$} & \multicolumn{2}{|c|}{$\begin{array}{c}\text { Intermediate } \\
\text { Principal } \\
\text { Stress }\end{array}$} & \multicolumn{2}{|c|}{$\begin{array}{c}\text { Minimum } \\
\text { Principal } \\
\text { Stress }\end{array}$} & \multicolumn{2}{|c|}{$\begin{array}{c}\text { Average } \\
\text { Misfit Angle } \\
\beta\end{array}$} \\
\hline & Ddir & Dip & Rake & & & Trend & Plunge & Trend & Plunge & Trend & Plunge & Mean & S.D. \\
\hline \multicolumn{14}{|l|}{ San Fernando } \\
\hline 1971 & $23^{\circ}$ & $52^{\circ}$ & $72^{\circ}$ & 76 & 0.54 & $-175^{\circ}$ & $5.2^{\circ}$ & $-84^{\circ}$ & $12^{\circ}$ & $73^{\circ}$ & $76^{\circ}$ & $24^{\circ}$ & $33^{\circ}$ \\
\hline Whittier 1987 & $0^{\circ}$ & $25^{\circ}$ & $90^{\circ}$ & 59 & 0.27 & $173^{\circ}$ & $3.2^{\circ}$ & $-96^{\circ}$ & $15^{\circ}$ & $71^{\circ}$ & $74^{\circ}$ & $33^{\circ}$ & $29^{\circ}$ \\
\hline \multicolumn{14}{|l|}{ Pasadena } \\
\hline 1988 & $337^{\circ}$ & $75^{\circ}$ & $4^{\circ}$ & 10 & 0.52 & $-162^{\circ}$ & $11^{\circ}$ & $-48^{\circ}$ & $63^{\circ}$ & $102^{\circ}$ & $24^{\circ}$ & $13^{\circ}$ & $10^{\circ}$ \\
\hline Upland 1990 & $310^{\circ}$ & $70^{\circ}$ & $0^{\circ}$ & 117 & 0.45 & $-180^{\circ}$ & $0.2^{\circ}$ & $-89^{\circ}$ & $77^{\circ}$ & $90^{\circ}$ & $13^{\circ}$ & $20^{\circ}$ & $19^{\circ}$ \\
\hline \multicolumn{14}{|l|}{ Sierra Madre } \\
\hline 1991 & $332^{\circ}$ & $50^{\circ}$ & $82^{\circ}$ & 30 & 0.33 & $169^{\circ}$ & $1.7^{\circ}$ & $-100^{\circ}$ & $15^{\circ}$ & $73^{\circ}$ & $74^{\circ}$ & $36^{\circ}$ & $38^{\circ}$ \\
\hline
\end{tabular}


earthquakes in western San Gabriel Valley shows coexistence of strike-slip and thrust faulting. To the south, the 1987 Whittier Narrows earthquake was caused by thrust faulting on the Elysian Park thrust system, dipping $25^{\circ}$ to the north (Hauksson and Jones, 1989). In between, the 1988 Pasadena earthquake most likely occurred on the east-northeast-striking and steeply dipping Raymond fault (Jones et al., 1990). To the north, the 1991 Sierra Madre earthquake occurred on the Clamshell-Sawpit fault, an offshoot of the Sierra Madre fault zone.

This pattern of seismicity shows that the ongoing north-south compression of the Los Angeles basin and central Transverse Ranges is accommodated by both the Elysian Park fold and thrust belt to the south and the Sierra Madre fault zone to the north. Some of this compression is also accommodated with lateral block movement along strike-slip faults such as the Raymond fault or the San Jose fault, which caused the 1988 and 1990 Upland earthquakes (Hauksson and Jones, 1991).

\section{Earthquake Potential}

The earthquake potential of the Sierra Madre fault zone is poorly understood, in part because the long-term geologic slip rate is not known along most of the segments of the Sierra Madre fault zone. At least two possible scenario earthquakes have to be considered for the Sierra Madre fault zone.

The first scenario earthquake is an $M 7.7$ rupturing almost the whole length of the Sierra Madre fault zone, a length of approximately $100 \mathrm{~km}$. The possibility of an M 7.7 earthquake was raised by Wesson et al. (1974) through comparison with the $1952 M_{S} 7.7$ Kern County earthquake. Although Crook et al. (1987) could only identify Holocene offsets along the Sierra Madre B segment, they concurred that an $M_{S} 7.7$ event was possible. They also simply stated that the repeat time for an $M 7.7$ earthquake was greater than $5000 \mathrm{yr}$.

The second scenario earthquake is an $M 6.4$ to 6.6 earthquake that would rupture one of the seven segments

\section{SIERRA MADRE FAULT : DEPTH CONTOURS AND SEGMENTATION}

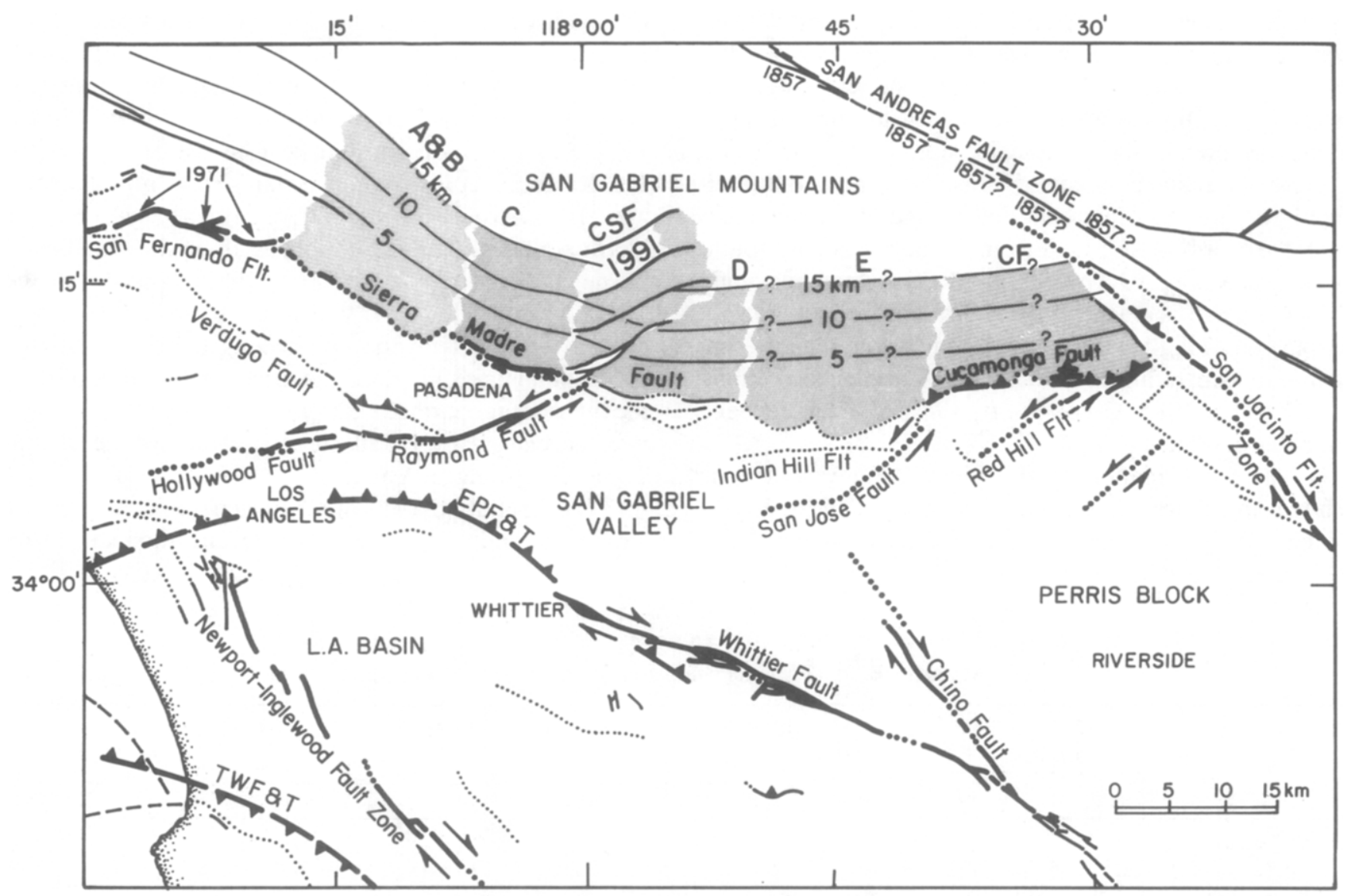

Figure 11. Map showing segmentation as shaded regions and depth contours of the Sierra Madre fault zone. Segmentation information is from Ehlig (1975), Proctor et al. (1972), Crook et al. (1987), and Wesnousky (1986). The depth contours are inferred from the distribution of aftershocks in the 1971 San Fernando and the 1991 Sierra Madre sequences. 
(Wesnousky, 1986). The repeat times for such earthquakes have been estimated along the San Fernando segment to be $200 \mathrm{yr}$ (Bonilla, 1973). Similarly, along the Cucamonga segment, the repeat time was estimated to be $700 \mathrm{yr}$ by Matti and Morton (1982). In a review study, Wesnousky (1986) proposed a maximum earthquake magnitude of 6.4 to 6.6 along each segment by comparison with the 1971 San Fernando earthquake.

The San Fernando and Cucamonga segments that have relatively short repeat times appear to behave, at least in some cases, as independent segments (Bonilla, 1973; Matti and Morton, 1982). They may break in San Fernando size ( $M 6.4$ to 6.6) earthquakes (Wesnousky, 1986). The $60-\mathrm{km}$ length of the fault between the two segments has been seismically quiescent at least since 1932 (Fig. 2) and has no extensive evidence of Holocene faulting (Crook et al., 1987). The occurrence of the 1991 Sierra Madre earthquake near this segment suggests, but does not require, that this segment is seismogenic and thus may rupture in infrequent major $(M \geqq 7)$ earthquakes. Alternatively, this segment of the fault may be aseismic, and the slip is transferred to the Elysian Park thrust system in the south by left-lateral faults such as the San Jose fault, as suggested by Hauksson and Jones (1991). None of the available data make it possible to discern between these two alternatives.

\section{Conclusions}

The occurrence of the 1991 Sierra Madre earthquake sequence suggests that the Clamshell-Sawpit fault, an offshoot of the Sierra Madre fault zone, is seismogenic. The 1971 San Fernando and the flurry of moderate-sized earthquakes since 1987 in the greater Los Angeles area have not released significant tectonic stress in the region. They have contributed to our understanding of the compressional tectonics associated with the big bend of the San Andreas fault. Left-lateral strike-slip faults allow crustal blocks to move out of the way to the west, while two thrust systems, the Elysian Park and the Sierra Madre, cause crustal thickening. The two end segments, San Fernando and Cucamonga faults, may rupture independently in $M 6.4$ to 6.6 earthquakes. The $60-\mathrm{km}$-long section of the Sierra Madre fault zone, extending along the range front from the west end of the Cucamonga fault to the east end of the San Fernando fault, had almost no background seismicity prior to the 1991 Sierra Madre earthquake. The occurrence of the 1991 earthquake suggests that this segment is capable of causing both moderate-sized and large earthquakes.

\section{Acknowledgments}

I thank L. Jones and D. Oppenheimer for critical review of the manuscript. I thank D. Morton, L. Silver, and K. Sieh for interesting discussions about the tectonics of the central Transverse Ranges. I am grateful to the seismic analysts of Caltech and the USGS for quick and competent processing of the data. This work was supported by USGS Grant No. 14-08-0001-G1761. Division of Geological and Planetary Sciences, California Institute of Technology, Contribution No. 5132. Southern California Earthquake Center Contribution No. 55.

\section{References}

Bonilla, M. G. (1973). Trench exposures across surface fault ruptures associated with San Fernando earthquake in San Fernando, California, earthquake of February 9, 1971, Vol. 3, U.S. Department of Commerce, Washington, D.C., 173-182.

Crook, R., Jr., C. R. Allen, B. Kamb, C. M. Payne, and R. J. Proctor (1987). Quaternary geology and seismic hazard of the Sierra Madre and associated faults, western San Gabriel Mountains, in Recent Reverse Faulting in the Transverse Ranges, California, D. M. Morton and R. F. Yerkes (Editors), U.S. Geol. Surv. Profess. Pap. 1339, 27-64.

Davis, T. L., J. Namson, and R. F. Yerkes (1989). A cross section of the Los Angeles area: seismically active fold and thrust belt, the 1987 Whittier Narrows earthquake and earthquake hazard, J. Geophys. Res., 94, 9644-9664.

Dreger, D. and D. Helmberger (1991). Source parameters of the Sierra Madre Earthquake from regional and local body waves, Geophys. Res. Lett. 18, 2015-2108.

Ehlig, P. L. (1975). Geologic framework of the San Gabriel Mountains, Bull. Calif. Div. Mines Geol. 196, 7-18.

Ehlig, P. L. (1981). Origin and tectonic history of the basement terrane of the San Gabriel Mountains, Central Transverse Ranges, in The Geotectonic Development of California, W. G. Ernst, Berlin, 253-283.

Gephart, J. W. and D. W. Forsyth (1984). An improved method for determining the regional stress tensor using earthquake focal mechanism data: application to the San Fernando earthquake sequence, J. Geophys. Res. 89, 9305-9320.

Hadley, D. and H. Kanamori (1977). Seismic structure of the Transverse Ranges, California, Geol. Soc. Am. Bull. 88, 1469-1478.

Hauksson, E. (1990). Earthquakes, faulting and stress in the Los Angeles Basin, J. Geophys. Res. 95, 15365-15394.

Hauksson, E. (1994). State of stress from focal mechanisms before and after the 1992 Landers earthquake sequence. Bull. Seism. Soc. Am. (in press).

Hauksson, E. and L. M. Jones (1989). The 1987 Whittier Narrows earthquake sequence in Los Angeles, southern California: seismological and tectonic analysis, J. Geophys. Res. 94, 9569-9590.

Hauksson, E. and L. M. Jones (1991). The 1988 and 1990 Upland earthquakes: left-lateral faulting adjacent to the Central Transverse Ranges, J. Geophys. Res. 96, 8143-8165.

Hauksson, E., L. M. Jones, T. L. Davis, L. K. Hutton, A. G. Brady, P. A. Reasenberg, A. J. Michael, R. F. Yerkes, P. Williams, G. Reagor, C. W. Stover, A. L. Bent, A. K. Shakal, E. Etheredge, R. L. Porcella, C. G. Bufe, M. J. S. Johnston, and E. Cranswick (1988). The 1987 Whittier Narrows earthquake in the Los Angeles metropolitan area, California, Science 239, 1409 1412.

Hudnut, K. W., Y. Bock, C. M. Machacek, and R. R. Zitola (199I). Geodetic Study of the Sierra Madre Earthquake (abstract), EOS, 72, 319.

Jennings, C. W. (1975). Fault map of California with volcanoes, thermal springs and thermal wells, 1:750,000 scale, geol. data map 1, Calif. Div. Mines and Geol. Sacramento. 
Johnson, C. E. (1983). CUSP-Automated processing and management for large regional networks (abstract), Earthquake Notes $54,13$.

Jones, L. M., K. E. Sieh, E. Hauksson, and L. K. Hutton (1990). The 3 December 1988 Pasadena, California earthquake: evidence for strike-slip motion on the Raymond fault, Bull. Seism. Soc. Am. 80, 474-482.

Kanamori, H., J. Mori, E. Hauksson, T. H. Heaton, L. K. Hutton, and L. M. Jones (1993). Determination of earthquake energy release and $M_{L}$ using TERRAscope, Bull. Seism. Soc. Am. 83, $330-346$.

Kisslinger, C. and L. M. Jones (1991). Properties of aftershock sequences in southern California, J. Geophys. Res. 96, 1194711958.

Klein. F. W. (1985). User's guide to HYPOINVERSE, a program for VAX and PC350 computers to solve for earthquake locations, U.S. Geol. Surv. Open-File Rept. 85-515.

Ma, K.-F. and H. Kanamori (1991). Aftershock sequence of the 3 December 1988 Pasadena earthquake, Bull. Seism. Soc. Am. 81, 2310-2319.

Matti, J. C. and D. M. Morton (1982). Geologic history of the Banning fault zone, southern California, Geol. Soc. Am. Abstr. Programs 14, 184.

Michael, A. J. (1984). Determination of stress from slip data: faults and folds, J. Geophys. Res. 89, 11517-11526.

Michael, A. J. (1987a). Use of focal mechanisms to determine stress: a control study, J. Geophys. Res. 92, 357-368.

Michael, A. J. (1987b). Stress rotation during the Coalinga aftershock sequence, J. Geophys. Res. 92, 7963-7979.

Michael, A. J. (1991). Spatial variations in stress within the 1987 Whittier Narrows, California, aftershock sequence: new techniques and results, J. Geophys. Res. 96, 6303-6319.

Michael, A. J., W. L. Ellsworth, and D. Oppenheimer (1990), Coseismic stress changes induced by the 1989 Loma Prieta, California earthquake, Geophys. Res. Lett. 17, 1441-1444.

Morton, D. M. and R. F. Yerkes (1987). Recent reverse faulting in the Transverse Ranges, California, U.S. Geol. Surv. Profess. Pap. 1339, 1-5.

Pechmann, J. C. (1987). Tectonic implications of small earthquakes in the central Transverse Ranges, in Recent Reverse Faulting in the Transverse Ranges, California, U.S. Geol. Surv. Profess. Pap. 1339, 97-111.
Proctor, R. J., R. Crook, M. H. McKeown, and R. L. Moresco (1972). Relation of known faults to surface ruptures, 1971 San Fernando earthquake, southern California, Geol. Soc. Am. Bull. 83, 16011618.

Reasenberg, P. and D. Oppenheimer (1985). FPFIT, FPPLOT and FPPAGE: Fortran computer programs for calculating and displaying earthquake fault-plane solutions, U.S. Geol. Surv. OpenFile Rept. 85-739, 4.

Reasenberg, P. A. and L. M. Jones (1989). Earthquake hazard after a mainshock in California, Science 243, 1173-1176.

Roecker, S. and W. L. Ellsworth (1978). VELEST, Fortran Program, U.S. Geological Survey, Menlo Park, California.

Savage, J. C., R. O. Burford, and W. T. Kinoshita (1975). Earth movements from geodetic measurements, Bull. Calif. Div. Mines Geol. 196, 175-186.

Stover, C. W. and B. G. Reagor (1991). Preliminary isoseismal map for the Sierra Madre, California, earthquake of June 28, 1991 UTC, U.S. Geol. Surv. Open File Rept. 91-388, 1-16.

Wald, D. J. (1992). Strong motion and broadband teleseismic analysis of the 1991 Sierra Madre, California, earthquake, J. Geophys. Res. 97, 11033-11046.

Wesnousky, S. G. (1986). Quaternary faults and seismic hazards in California, J. Geophys. Res. 91, 12587-12632.

Wesson, R. L., R. A. Page, D. M. Boore, and R. F. Yerkes (1974). Expectable earthquakes and their ground motions in the Van Norman Reservoirs Area, Geol. Surv. Circular 691-A, B, B1B9.

Whitcomb, J. H., C. R. Allen, J. D. Garmany, and J. A. Hileman (1973). San Fernando earthquakes series, 1971: focal mechanisms and tectonics, Rev. Geophys. 11, 693-730.

Ziony, J. I. and R. F. Yerkes (1985). Evaluating earthquake and surface faulting potential, in Evaluating Earthquake Hazards in the Los Angeles Region-An Earth Science Perspective, J. I. Ziony (Editor), U.S. Geol. Surv. Profess. Pap. 1360, 43-91.

Zumberge, J. F., K. J. Hurst, U. J. Lindqwister, F. H. Webb, and G. Blewitt (1991). Measurements of the Sierra Madre earthquake with the Global Positioning System (abstract), EOS 72, 319.

California Institute of Technology

Pasadena, California 91125

Manuscript received 28 May 1993. 